\title{
APRESIASI MASYARAKAT KABUPATEN PURWAKARTA TERHADAP SIARAN LOKAL JATILUHUR TELEVISI
}

\author{
Dida Dirgahayu \\ Peneliti pada Balai Pengkajian dan Pengembangan Komunikasi dan Informatika Bandung \\ (Naskah diterima 2 Maret 2011 - Revisi 5 April 2011)
}

\begin{abstract}
Abstrak
Lembaga penyiaran televisi lokal sebagaimana diatur dalam Undang-Undang No. 32 Tahun 2002 Tentang Penyiaran, termasuk dalam lembaga Penyiaran swasta. Definisi televisi lokal tidak jauh berbeda dengan televisi komersial nasional, yaitu lembaga penyiaran yang bersifat komersial berbentuk badan hukum Indonesia yang bidang usahanya hanya menyelenggarakan jasa penyiaran televisi, hanya daya jelajahnya saja yang berbeda. Masalah yang diteliti dalam penelitian ini adalah bagaimana apresiasi masyarakat terhadap siaran lokal Jatiluhur Televisi (Jatiluhur TV) yang berada di Kabupaten Purwakarta, Provinsi Jawa Barat. Tujuan dari penelitian ini adalah untuk mengetahui tingkat pengetahuan dan pemahaman masyarakat, penilaian dan kepuasan masyarakat terhadap siaran lokal Jatiluhur TV sebagai lembaga penyiaran televisi lokal. Teknik pengumpulan data dilaksanakan dengan penyebaran angket, wawancara, studi pustaka dan dokumentasi. Hasil penelitian menunjukkan bahwa masyarakat di Kabupaten Purwakarta memberikan apresiasi yang tinggi dan merasakan manfaat dari siaran lokal Jatiluhur TV, walaupun pada satu sisi masyarakat tidak puas dengan fungsi pendidikan yang dilakukan oleh Jatiluhur TV.
\end{abstract}

Kata kunci : Apresiasi, dan siaran lokal Jatiluhur TV

\section{Abstract}

Local television broadcasters as they set out in UU 32 of 2002 on Broadcasting, including in private broadcasting institutions. The definition of local television is not much different from the national commercial television, which is the commercial broadcasters in the form of an Indonesian legal entity that line of business only provides services for television broadcasting, only the range are different. Problems examined in this research is how the public appreciation of local broadcast television Jatiluhur (Jatiluhur TV) located in Purwakarta Regency, West Java Province. The purpose of this research was to discover the level of knowledge and understanding of society, people's satisfaction and valuation to local broadcast TV Jatiluhur as local television broadcasters. Techniques of data collection carried out by questionnaire, interview, literature study and documentation. The result showed that people in Purwakarta Regency give the highest appreciation and feel the benefits from local broadcast TV Jatiluhur, although on the one hand people are not satisfied with the educational function performed by Jatiluhur TV.

Key words: Appreciation, and local broadcast TV Jatiluhur

\section{PENDAHULUAN}

Seiring dengan tumbuhnya otonomi daerah dan terbitnya Undang-undang Penyiaran telah memberi peluang bermunculannya lembaga penyiaran lokal, baik radio, televisi maupun lembaga penyiaran lainnya. Hal ini didukung pula oleh komunitas lokal yang merasa berkepentingan dengan eksistensi penyiaran lokal karena selama ini aspirasi dan informasi daerahnya kurang terakomodasi oleh lembaga penyiaran nasional, khususnya siaran televisi.

Perkembangan teknologi komunikasi yang demikian pesat dewasa ini menyebabkan terjadinya perubahan dalam masyarakat, termasuk perubahan perilaku dalam berkomunikasi, semakin banyak akses 
informasi dan semakin mudahnya lalu lintas informasi dari berbagai penjuru dunia baik dari segi kualitas maupun kuantitas.

Terjadinya akses informasi dari berbagai media kepada khalayak sebagai pengguna media memiliki banyak pilihan dan dengan bebas pula mengakses informasi dan media massa yang dikehendaki. Bahkan muncul kecenderungan khalayak memilih program yang disiarkan dari media yang dominan diminati yaitu siaran televisi.

Hal ini tidak saja karena keunggulan televisi sebagai media pandang dengar (media visual) tetapi juga karena sifatnya yang acceptable terhadap perkembangan teknologi komunikasi baru. Di Indonesia fenomena ini sudah mulai terjadi sejak tahun 1986, saat diterapkan kebijaksanaan udara terbuka (open sky policy) oleh pemerintah sehubungan peluncuran Satelit Komunikasi Domestik (SKSD) Palapa tahun 1976, kondisi ini menyebabkan pemerintah dengan sendirinya melegalisasi penggunaan antena parabola yang sudah ada di masyarakat. Konsekuensi dari kebijakan ini adalah tidak ada lagi pembatasan masuknya informasi global di Indonesia.

Secara ideal kehadiran televisi sangat dinantikan komunitas lokal dan menjadi harapan besar bagi masyarakat dalam mengakses berbagai informasi. Unsur kedekatan (proksimitas) pasti terpenuhi oleh televisi lokal apalagi sebagaimana tercantum dalam UU No: 22 tahun 1999 tentang Pemerintahan Daerah, keberadaan televisi lokal menjadi sangat berharga baik bagi pemerintah daerah maupun bagi masyarakat.

Demikian pula dengan keberadaan Jatiluhur TV sebagai media penyiaran lokal di Kabupaten Purwakarta, Provinsi Jawa Barat, meskipun sampai saat ini siaran televisi nasional masih dominan, keberadaan televisi lokal merupakan salah satu alternatif bagi komunitas lokal untuk memenuhi kebutuhan informasi dan hiburan.

Kondisi inilah yang mendorong perlunya dilakukan penelitian untuk mengetahui keadaan yang sebenarnya tentang bagaimana apresiasi masyarakat di Kabupaten Purwakarta terhadap siaran lokal Jatiluhur TV. Penelitian ini perlu dilakukan karena dengan meningkatnya kuantitas dan kualitas siaran televisi dan beragam media lainnya, menjadikan masyarakat mempunyai bahan pembanding terutama dalam era regulasi media massa dan era kebebasan mengeluarkan pendapat, transparansi serta tidak adanya lagi penyensoran informasi melalui ragam media.

Permasalahan pokok dari penelitian ini adalah: Bagaimana apresiasi masyarakat Kabupaten Purwakarta terhadap siaran lokal Jatiluhur TV sebagai lembaga penyiaran televisi lokal? Berdasarkan permasalahan pokok di atas, identifikasi masalahnya adalah :

1. Bagaimana pengetahuan dan pemahaman masyarakat Kabupaten Purwakarta terhadap fungsi media televisi lokal?

2. Bagaimana penilaian masyarakat Kabupaten Purwakarta terhadap keberadaan Jatiluhur TV sebagai lembaga penyiaran televisi lokal?

3. Bagaimana kepuasan masyarakat Kabupaten Purwakarta terhadap keberadaan Jatiluhur TV sebagai lembaga penyiaran televisi lokal?

Tujuan penelitian ini adalah untuk mengetahui :

1. Pengetahuan dan pemahaman masyarakat Kabupaten Purwakarta terhadap fungsi media televisi lokal.

2. Penilaian masyarakat Kabupaten Purwakarta terhadap keberadaan Jatiluhur TV sebagai lembaga penyiaran televisi lokal.

3. Kepuasan masyarakat Kabupaten Purwakarta terhadap keberadaan Jatiluhur TV sebagai lembaga penyiaran televisi lokal.

Penelitian ini layak dilakukan karena bermanfaat untuk memperoleh gambaran tentang apresiasi masyarakat Kabupaten Purwakarta terhadap keberadaan Jatiluhur TV sebagai lembaga penyiaran televisi lokal.

Manfaat praktis penelitian ini untuk menggambarkan pemahaman, pengetahuan dan kepuasan masyarakat terhadap keberadaan Jatiluhur TV sebagai lembaga penyiaran televisi lokal. 


\section{LANDASAN KONSEP}

Apresiasi adalah suatu proses yang kompleks di mana kita menerima dan menyadap informasi dari lingkungan (Fleming \& Levie, 1978). Persepsi juga merupakan proses psikologis sebagai hasil penginderaan serta proses akhir dari persepsi mempunyai implikasi penting untuk bertingkah lakunya seseorang dan akan menentukan bagaimana ia akan berinteraksi dan bereaksi baik atau buruk pada obyek yang dipersepsi tersebut (www.infoskripsi.com).

Teori-teori yang berorientasi kognitif adalah teori-teori yang menitikberatkan proses-proses sentral (misalnya sikap, ide, dan harapan) untuk menerangkan tingkah. Teori-teori kognitif di lain pihak lebih banyak mempelajari pembentukan konsep, berpikir dan membangun pengetahuan" (Sarwono, 1984: 89). Kognisi menurut Scheerer, adalah proses sentral yang menghubungkan peristiwa-peristiwa di luar (eksternal) dan di dalam (internal) diri sendiri. Penekanan Scheerer tidak hanya peristiwa-peristiwa yang sifatnya eksternal tetapi lebih jauh adalah peristiwa yang ada dalam dirinya atau faktor internal. Sedangkan Festinger, kognisi adalah elemen-elemen kognitif, yaitu hal-hal yang diketahui oleh seseorang tentang dirinya sendiri, tentang tingkah lakunya dan tentang keadaan di sekitarnya. Scott mengatakan, struktur kognisi adalah struktur yang terdiri dari elemen-elemen berupa ide-ide yang secara sadar dipertahankan oleh seseorang atau satu set ide-ide yang dipertahankan oleh orang yang bersangkutan dan setiap waktu tersedia bagi kesadaran. (Severin Tankard 2005: 297).

Komponen kognisi dalam membentuk pengetahuan memiliki keterkaitan yang sangat erat dengan faktor ekonomi seperti yang dikemukakan Tichenor, Donohue, dan Olien dalam hipotesisnya mengenai kesenjangan pengetahuan, yakni " Ketika pemasukan informasi media massa ke sistem sosial meningkat, segmen-segmen populasi dengan status sosial ekonomi yang lebih rendah, sehingga kesenjangan pengetahuan di antara segmen tersebut cenderung melebar daripada menyempit (Severin-Tankard 2003: 295).
Dalam kaitannya dengan penelitian ini, maka apresiasi masyarakat Kabupaten Purwakarta terhadap siaran lokal Jatiluhur TV sebagai lembaga penyiaran televisi lokal akan ditentukan dari penginderaan serta proses kesadaran yang pada akhirnya mendorong pada tingkah laku dan reaksi atas keberadaan persepsi masyarakat Kabupaten Purwakarta terhadap siaran lokal Jatiluhur TV sebagai lembaga penyiaran televisi lokal sehingga membentuk proses berpikir.

Apresiasi dan sikap merupakan kecenderungan bereaksi terhadap objekobjek, di mana kecenderungan bereaksi ini merupakan cara yang khas tergantung dari motivasi, emosi, dan proses kognitifnya. Operasional konsep dari persepsi mengacu kepada tiga komponen sebagai indikator, di mana masing-masing mempunyai fungsi yang diarahkan terhadap objek tertentu atau stimulus tertentu. Indikator itu adalah :

1. Komponen kognitif, yaitu pengetahuan pengalaman, pengertian, pemahaman masyarakat Kabupaten Purwakarta terhadap siaran lokal Jatiluhur TV sebagai lembaga penyiaran televisi lokal.

2. Komponen afektif, yaitu penilaian menyangkut masalah emosional subjektif seseorang terhadap suatu objek sikap. Objek dirasakan sebagai hal yang menyenangkan, hal disukai atau tidak. Reaksi ini dipengaruhi oleh kepercayaan atau apa yang kita percayai sebagai benar dan berlaku bagi suatu objek.

3. Komponen konatif, berhubungan dengan kecenderungan untuk bereaksi, bertingkah laku, kepuasan dengan cara tertentu, tapi konatif ini tidak meramalkan tingkah laku aktual itu sendiri.

Terdapat beberapa model komunikasi yang terbagi dalam dua bagian, yaitu model linear dan model sirkuler. Model linear terdiri dari formula Lasswell dan model Braddock serta model Shannon dan Weaver (model matematika). Sementara model sirkuler diantaranya adalah model De Fleur.

Dalam penelitian ini, model komunikasi yang dipakai adalah model komunikasi Lasswell. Lasswell menyebutkan terdapat 5 unsur penting dalam proses komunikasi, yaitu 
who, say what, in which channel, to whom dan with what effect. Model ini sangat fleksibel dan dapat diterapkan pada proses komunikasi massa pada umumnya. Kelima unsur tersebut erat kaitannya satu dengan lainnya. Komunikator menyampaikan pesanpesannya dengan menggunakan media massa kepada sasaran, selanjutnya sasaran menyampaikan umpan balik. Apabila diproyeksikan pada lembaga siaran lokal, maka kegiatan penyampaian pesan dapat dilakukan oleh stasiun siaran lokal muatan dan kemasan lokal dan sangat beragam sesuai dengan karakteristik dan kebutuhan masyarakat setempat (lokal).

Masyarakat luas yang merasa terpenuhi kebutuhan informasi, hiburan, pendidikan yang sesuai dengan karakteristik lokalnya, akan memberikan respon (feedback) terhadap pesan yang diterima maupun kepada media penyampai pesannya. Pada akhirnya proses komunikasi tersebut akan berdampak pada dukungan masyarakat terhadap eksistensi lembaga penyiaran lokal di masing-masing daerah. (Gerungan, 1996: 150).

\section{Apresiasi}

Apresiasi adalah suatu tingkat pemahaman, sikap (kecenderungan tindakan) (Kamus Umum Bahasa Indonesia, 2003). Dalam konteks penelitian ini apresiasi adalah kecenderungan pemahaman, pengetahuan, kepuasan dan saran pemirsa terhadap fungsi televisi yang ada atau beredar di wilayah Kabupaten Purwakarta,

Menurut Kotler (2003), apresiasi ialah rangsangan yang dilanjutkan dengan pemberian makna kepada rangsangan yang diterima. Terdapat dua jenis persepsi, yaitu persepsi aktif dan persepsi non aktif. Persepsi terdiri dari 3 peringkat proses, yaitu proses pemilihan rangsangan, proses penyusunan dan membentuk struktur tentang yang dilihat, dan proses menginterpretasikan atau memberi makna tentang apa yang diperhatikan. Apresiasi maupun persepsi seseorang melibatkan 3 proses, yaitu proses pembentukan impresi atau gambaran tentang objek, proses penyusunan tanggapan/ maklumat terhadap objek, dan proses pemahaman makna terhadap objek. Seseorang yang termotivasi akan siap bertindak karena dipengaruhi oleh persepsi terhadap objek tertentu. (www.scribd.com)

$$
\text { Apresiasi ataupun persepsi }
$$

berhubungan dengan keyakinan (belief), adalah gambaran pemikiran yang dianut tentang suatu hal. Keyakinan berdasarkan pengetahuan, pendapat, atau kepercayaan (faith). Sikap (attitude) adalah evaluasi, perasaan emosional, dan kecenderungan pendapat yang menguntungkan atau tidak menguntungkan serta bertahan lama dalam diri seseorang terhadap suatu objek atau gagasan. (www.scribd.com).

\section{Jatiluhur TV}

Jatiluhur TV berdiri pada tahun 2006 di Purwakarta dengan kekuatan pemancar $2 \mathrm{KW}$. Didukung dengan tenaga SDM yang kreatif serta mempunyai visi yang sama, sampai saat ini Jatiluhur TV menjadi satu-satunya stasiun TV di PURWASUKA (Purwakarta, Subang, Karawang).

\section{Televisi Swasta Lokal}

Definisi televisi lokal tidak jauh berbeda dengan definisi televisi komunitas, hanya daya jelajahnya saja yang berbeda. Latar belakang legitimasi politis atas lembaga penyiaran swasta lokal berawal dari pertimbangan yang bersifat ekonomis, yaitu untuk mengeliminir monopoli kepemilikan media televisi oleh pemodal tertentu, serta untuk melakukan desentralisasi modal dan akumulasi keuntungan bisnis penyiaran. ( Sumadiria, 2005: 7).

\section{Televisi Lokal}

Menurut Undang-Undang No. 32 Tahun 2002 Tentang Penyiaran, penyiaran televisi adalah media komunikasi massa dengar pandang, yang menyalurkan gagasan dan informasi dalam bentuk suara dan gambar secara umum, baik terbuka maupun tertutup, berupa program yang teratur dan berkesinambungan.

Lembaga penyiaran televisi lokal 
sebagaimana diatur dalam Undang-Undang No. 32 Tahun 2002 tentang Penyiaran, termasuk dalan lembaga Penyiaran swasta. Definisi televisi lokal tak jauh berbeda dengan televisi komersial nasional, yaitu lembaga penyiaran yang bersifat komersial berbentuk badan hukum Indonesia yang bidang usahanya hanya menyelenggarakan jasa penyiaran televisi, hanya daya jelajahnya saja yang berbeda.

Mengacu kepada Undang-Undang tersebut pasal 16, maka eksistensi lembaga penyiaran televisi lokal dapat diukur oleh indikator :

- Bentuk badan hukum

- Kepemilikan

- Modal awal

- Penyertaan modal asing

- Kesempatan bagi karyawan untuk memiliki saham

- Sumber pembiayaan yang bersumber dari iklan dan kegiatan lain yang berhubungan dengan penyiaran.

Latar belakang legitimasi politis atas lembaga penyiaran swasta lokal berawal dari pertimbangan yang bersifat ekonomis, yaitu untuk mengeliminir monopoli kepemilikan media televisi oleh pemodal tertentu, serta untuk melakukan desentralisasi modal dan akumulasi keuntungan bisnis penyiaran.

Definisi konsep adalah definisi yang didasarkan atas sifat-sifat hal yang didefinisikan yang dapat diamati, yang akan menunjuk alat pengambil data yang cocok digunakan atau mengacu pada bagaimana mengukur suatu variabel.

1. Apresiasi : suatu tingkat pemahaman, sikap (kecenderungan tindakan) (Kamus Umum Bahasa Indonesia, 2003). Dalam konteks penelitian ini apresiasi adalah kecenderungan pemahaman, pengetahuan, penilaian dan kepuasan pemirsa terhadap siaran Jatiluhur TV yang ada di Kabupaten Purwakarta. Indikatornya adalah : pemahaman, pengetahuan, penilaian, kepuasan, serta saran dan harapan masyarakat.

2. Masyarakat Kabupaten Purwakarta, yang dimaksud dengan masyarakat Kabupaten Purwakarta adalah masyarakat yang menetap / berdomisili di Kabupaten
Purwakarta Provinsi Jawa Barat. Terjangkau dan menjadi penonton dari Jatiluhur TV sebagai lembaga penyiaran televisi lokal.

3. Televisi lokal, indikatornya : fungsi informasi, fungsi hiburan, fungsi pendidikan, dan fungsi kontrol yang dimiliki media televisi.

\section{METODE PENELITIAN}

Penelitian ini bersifat deskriptif (descriptive research), bertujuan untuk menggambarkan secara sistematis, akurat, dan faktual, mengenai situasi-situasi, faktafakta dari populasi tertentu. Menggambarkan apresiasi masyarakat terhadap siaran televisi lokal. Penelitian dilakukan melalui pengumpulan data kuantitatif.

Teknik penelitian ini adalah survei. Survei merupakan satu metode penelitian yang teknik pengambilan datanya dilakukan melalui pertanyaan tertulis atau lisan (Suryabrata, 1983: 19)

Populasi penelitian ini adalah masyarakat penonton Jatiluhur TV yang bertempat tinggal di Kabupaten Purwakarta. Sampel ditentukan secara purposive yaitu 100 orang.

Pengolahan data dilakukan dengan mengolah jawaban hasil kuesioner, dimasukan dalam tabel frekuensi dan persentase yang selanjutnya diinterpretasikan dan dianalisis.

\section{HASIL PENELITIAN DAN PEMBAHASAN}

\section{Analisis Pengetahuan dan Pemahaman Masyarakat Kabupaten Purwakarta Terhadap Fungsi Televisi Lokal}

Untuk mengetahui bagaimana apresiasi masyarakat di Kabupaten Purwakarta terhadap siaran lokal Jatiluhur TV sebagai media televisi lokal, terlebih dahulu harus diketahui sarana komunikasi dan media informasi apa saja yang dimiliki oleh masyarakat, khususnya media televisi. 
Selanjutnya diukur oleh intensitas atau frekuensi menonton siaran televisi, waktu dan lamanya menonton siaran televisi, siaran televisi mana saja yang sering ditonton dan materi siaran apa saja yang diminati.

Kepemilikan sarana komunikasi dan media informasi sebagai salah satu sumber informasi sangat berpengaruh terhadap responden dalam memahami, mengetahui, serta memberikan tanggapannya terhadap fungsi media televisi.

Pemilikan sarana komunikasi dan media informasi oleh responden dapat menggambarkan kebutuhan pemiliknya terhadap berbagai informasi yang berkaitan dengan kehidupan dan lingkungannya.

Perolehan data dari sarana media informasi menyatakan, sebanyak 96 responden $(96 \%)$ memiliki pesawat televisi, 4 responden (4\%) tidak memiliki pesawat televisi karena masih bersama orang tuanya (pelajar). Sebanyak 92 responden $(92 \%)$ memiliki pesawat radio dan 8 responden $(8 \%)$ tidak memiliki pesawat radio. Sebanyak 47 responden $(47 \%)$ memiliki juga fasilitas internet.

Selain media televisi, radio dan surat kabar, sebagian responden menyatakan membaca majalah dan media lainnya, namun dalam kapasitas yang kecil dan tidak pasti frekuensinya (kadang-kadang).

Intensitas responden dalam menonton dan mengikuti tayangan acara di televisi terungkap bahwa sebagian besar responden 27 responden (27\%) menyatakan sangat sering menonton acara siaran di televisi, 39 responden (39\%) menyatakan sering, 21 responden $(21 \%)$ menyatakan cukup sering, dan 13 responden (13\%) menyatakan kadangkadang menonton siaran televisi.

Waktu yang dipergunakan oleh responden untuk menonton dan mengikuti siaran televisi, sebagian besar responden yaitu sebanyak 52 responden (52\%) menyatakan menonton antara 1 sampai dengan 3 jam. Sebanyak 23 responden (23\%) menyatakan menonton televisi antara 3 sampai dengan 5 jam, 14 responden (14\%) menonton antara 5 sampai dengan 7 jam, dan 11 responden (11\%) menyatakan hanya menonton kurang dari satu jam.
Perbedaan lamanya mengikuti perkembangan isu di televisi ini disebabkan karena masing-masing responden mempunyai kesempatan dan kesibukan yang berbedabeda.

Data tentang siaran stasiun televisi yang diikuti, dapat terlihat bahwa hampir seluruh responden mengikuti seluruh siaran televisi yang tersiar di daerahnya. Terdapat hal yang menarik, bahwa 87 responden (87\%) masih mengikuti siaran dari Televisi Republik Indonesia (TVRI) Jakarta, dan seluruh (100\%) responden menonton Jatiluhur TV. Hal ini menepis pendapat atau anggapan sebagian besar orang yang menyatakan bahwa TVRI telah ditinggalkan pemirsanya.

Rating kedua stasiun televisi yang diikuti adalah stasiun Televisi Pendidikan Indonesia (TPI) sebanyak 93 responden (93\%) diikuti stasiun SCTV dan RCTI yang diikuti oleh masing-masing 89 responden $(89 \%)$ serta stasiun televisi lainnya yang pada kenyataannya mempunyai rating tinggi sebagai stasiun televisi nasional yang ditonton oleh responden.

Data yang diperoleh menggambarkan bahwa 94 responden $(94 \%)$ sangat mengetahui tentang fungsi televisi lokal sebagai media informasi, dan 6 responden $(6 \%)$ tidak mengetahui fungsi televisi sebagai media informasi.

Pengetahuan responden tentang fungsi televisi sebagai media hiburan, tergambar dalam data sebagai berikut. Bahwa seluruh responden yaitu 100 responden (100\%) mengetahui tentang fungsi televisi sebagai media hiburan.

Tentang fungsi televisi sebagai media pendidikan, sebanyak 63 responden (63\%) mengetahui tentang fungsi televisi sebagai media pendidikan, dan 37 responden $(37 \%)$ tidak mengetahui fungsi televisi sebagai media pendidikan. Sebanyak 34 responden (34\%) menyatakan sangat mengetahui bahwa media televisi mempunyai fungsi sebagai media kontrol, dan 66 responden (66\%) tidak mengetahui tentang fungsi kontrol media televisi.

Kepemilikan sarana komunikasi dan media informasi sebagai salah satu sumber informasi sangat berpengaruh terhadap 
responden dalam memberikan memahami, mengetahui, serta memberikan tanggapannya terhadap fungsi media televisi. Pemilikan sarana komunikasi dan media informasi oleh responden dapat menggambarkan kebutuhan pemiliknya terhadap berbagai informasi yang berkaitan dengan kehidupan dan lingkungannya. Data yang diperoleh menunjukkan bahwa pesawat televisi merupakan media informasi yang paling dominan dalam kehidupan masyarakat .

Sebagian besar masyarakat di Kabupaten Purwakarta mengikuti seluruh siaran televisi yang tersiar di daerahnya.

Tentang keberadaan Jatiluhur TV, masyarakat di Kabupaten Purwakarta mengetahui keberadaannya dan hampir sebagian besar mengikuti siarannya.

Tentang materi siaran yang ditonton pada siaran Jatiluhur TV, sebagian besar masyarakat menonton program kebudayaan lokal, siaran hiburan, diikuti dengan menonton program siaran pendidikan dan olahraga yang terjadi di wilayah Kabupaten Purwakarta dan sekitarnya.

Sebagian besar masyarakat telah mengetahui dan memahami fungsi Jatiluhur TV sebagai media informasi, media hiburan, media pendidikan, serta sebagai media kontrol. Hal ini menunjukkan bahwa selain sebagai bagian dari kehidupan dan lingkungan sosialnya, fungsi media televisi telah dipahami secara normatif. Dengan pemahaman tersebut, masyarakat dapat menilai baik buruknya, bermanfaat atau tidaknya tayangan televisi, baik dari sudut materi siaran maupun penyajiannya.

Seluruh masyarakat yang terwakili dalam populasi penelitian ini telah mengetahui bahwa Jatiluhur TV berfungsi sebagai media informasi dan sekaligus sebagai media hiburan. Tetapi walaupun dalam persentase yang lebih kecil, tidak semua masyarakat mengetahui Jatiluhur TV mempunyai fungsi sebagai media pendidikan. Sama halnya dengan fungsi kontrol, tidak seluruh manyarakat di Kabupaten Purwakarta yang menonton Jatiluhur TV mengetahui dan memahami bahwa televisi lokal tersebut berfungsi sebagai media kontrol.

\section{Penilaian Masyarakat Kabupaten Purwakarta Terhadap Keberadaan Jatiluhur TV Sebagai Lembaga Penyiaran Televisi Lokal}

Tentang materi siaran yang ditonton pada siaran Jatiluhur TV, Sebanyak 36 responden (36\%) menyatakan menonton siaran berita, 67 responden $(67 \%)$ menonton siaran hiburan. 13 responden (13\%) menonton siaran olahraga. Sebanyak 87 responden (87\%) menonton siaran kebudayaan lokal, 13 responden (13\%) menonton siaran asing serta sebanyak 21 responden (21\%) menyatakan menonton siaran pendidikan.

Data tentang program siaran regular yang paling mencerminkan budaya lokal pada siaran lokal Jatiluhur TV, seperti terlihat pada tabel 1 .

Data tentang program siaran regular yang paling disukai pada siaran lokal Jatiluhur TV, Sebanyak 36 responden (36\%) menyatakan menonton program siaran kawih sunda, 21 responden $(21 \%)$ menonton siaran warta sunda, 14 responden (14\%) menonton kabar purwasuka, 11 responden (11\%) menyukai siaran selintas jatiluhur, dan diikuti oleh program, jatiluhur 9, serta on your attention.

Selain program siaran reguler, Jatiluhur TV mengetengahkan program siaran khusus. Data menunjukkan bahwa siaran khusus yang paling mencerminkan budaya lokal adalah profil usaha, di mana sebanyak 39 responden (39\%) memilihnya. Sebanyak 31 responden (31\%) menjawab siaran rumor rumeuk, 23 responden $(23 \%)$ menjawab siaran rukun wargaku, dan 7 responden (7\%) menjawab program siaran khusus dendang asyik sebagai siaran lokal yang paling mencerminkan budaya lokal.

Data tentang program siaran yang paling disukai pada siaran lokal Jatiluhur TV, Sebanyak 37 responden (37\%) menyatakan menyukai menonton program siaran dendang asyik, 23 responden $(23 \%)$ menyukai siaran rukun wargaku, 21 responden (21\%) menyukai tontonan rumor rumeuk, dan 19 responden (19\%) menyukai siaran profil usaha. 
Tabel 1

Program Siaran Reguler Yang Paling Mencerminkan Budaya Lokal

\begin{tabular}{|c|l|c|c|}
\hline No & \multicolumn{1}{|c|}{ Uraian } & Jumlah & \% \\
\hline 1 & Kabar Purwasuka & 13 & 13 \\
\hline 2 & Selintas Jatiluhur & 9 & 9 \\
\hline 3 & Jatiluhur 9 & 9 & 9 \\
\hline 4 & Warta Sunda & 23 & 23 \\
\hline 5 & On Your Atenttion & 4 & 4 \\
\hline 6 & Kawih Sunda & 42 & 42 \\
\hline & Total & $\mathbf{1 0 0}$ & $\mathbf{1 0 0}$ \\
\hline
\end{tabular}

Sumber : Data penelitian tahun 2009

Tentang bahasa yang dipergunakan, sebanyak 72 responden $(72 \%)$ menyatakan bahwa bahasa yang dipergunakan pada program siaran Jatiluhur TV mencerminkan budaya lokal setempat, dan 28 responden (28\%) menilai tidak mencerminkan budaya lokal .

Sebanyak 83 responden $(83 \%)$ menyatakan bahwa program siaran Jatiluhur TV mencerminkan budaya lokal setempat, dan 17 responden $(17 \%)$ menilai bahwa siaran Jatiluhur TV tidak mencerminkan budaya lokal .

Mengenai manfaat yang diperoleh, masyarakat di Kabupaten Purwakarta menyatakan bahwa siaran lokal Jatiluhur TV memberikan manfaat terhadap masyarakat penontonnya.

Masyarakat menilai bahwa program siaran Jatiluhur TV telah mencerminkan media televisi lokal melalui berbagai program siaran. Yaitu Kabar Purwasuka yang berisikan tentang kabar sosial, budaya, politik, ekonomi, dan kabar tentang situasi keamanan yang ada di wilayah Kabupaten Purwakarta. Program siaran Selintas Jatiluhur, yang berisikan siaran seni dan budaya lokal, serta seputar peristiwa kriminal. Selain itu, masyarakat menilai keberadaan Jatiluhur TV sebagai stasiun televisi lokal tercermin dari program siaran lainnya, seperti Jatiluhur 9, dan kawih Sunda.

Diantara berbagai program siaran yang ditayangkan oleh Jatiluhur TV, sebagian besar masyarakat menyukai program siaran Kawih Sunda, siaran Warta Sunda, diikuti oleh siaran Selintas Jatiluhur, On Your Atenttion, dan program siaran Jatiluhur 9 yang kesemuanya masuk dalam kategori program siaran reguler Jatiluhur TV. Selain penilaian tentang kategori program siaran reguler Jatiluhur TV, sebagian besar masyarakat menyukai siaran Profil Usaha, Rumor rumeuk, dan siaran lainnya seperti Rukun wargaku serta Dendang Asyik yang masuk dalam kategori siaran khusus Jatiluhur TV.

Secara umum, masyarakat di Kabupaten Purwakarta menilai bahwa stasiun televisi lokal Jatiluhur TV telah mampu menjadi stasiun televisi lokal yang mencerminkan budaya lokal di Kabupaten Purwakarta. Masyarakat menilai bahwa keberadaan Jatiluhur TV bermanfaat dan dapat ikut menunjang budaya lokal yang ada di wilayah Jatiluhur.

\section{Kepuasan Masyarakat Kabupaten Purwakarta Terhadap Keberadaan Jatiluhur TV Sebagai Lembaga Penyiaran Televisi Lokal}

Data tentang kepuasan terhadap fungsi informasi, hiburan, pendidikan, dan kepuasan terhadap fungsi kontrol. Dalam hal fungsi informasi media televisi, 89 responden $(89 \%)$ puas, dan 11 responden (11\%) menyatakan 
Tabel 2

Kepuasaan Terhadap Jatiluhur

\begin{tabular}{|c|l|c|c|}
\hline No & \multicolumn{1}{|c|}{ Intensitas } & Jumlah & $\mathbf{\%}$ \\
\hline 1 & Sangat puas & 93 & 93 \\
\hline 2 & Puas & 7 & 7 \\
\hline \multicolumn{2}{|c|}{ Total } & $\mathbf{1 0 0}$ & $\mathbf{1 0 0}$ \\
\hline
\end{tabular}

Sumber : hasil penelitian 2009

tidak puas dengan fungsi informasi Jatiluhur TV.

Kepuasan terhadap fungsi hiburan, sebanyak 92 responden (92\%) menyatakan sangat puas, dan 8 responden $(8 \%)$ menyatakan tidak puas dengan fungsi hiburan yang dilakukan Jatiluhur TV.

Sebanyak 32 responden (32\%) menyatakan sangat puas terhadap fungsi pendidikan , 68 responden (68\%) tidak puas dengan fungsi pendidikan pada Jatiluhur TV.

Kepuasan tentang fungsi kontrol media televisi diperoleh data sebagai berikut, 68 responden $(68 \%)$ menyatakan puas, dan 32 responden $(32 \%)$ menyatakan tidak puas dengan fungsi kontrol Jatiluhur TV sebagai media televisi lokal.

Kepuasan responden terhadap berbagai program siaran yang ditayangkan oleh Jatiluhur TV, seperti yang tergambar pada tabel 2.

Masyarakat menyatakan puas terhadap fungsi informasi, fungsi hiburan, dan fungsi kontrol yang dijalankan oleh Jatiluhur TV. Namun demikian, masyakat merasa tidak puas dengan fungsi pendidikan Jatiluhur TV sebagai lembaga penyiaran televisi lokal.

Dengan kata lain, sekalipun masyarakat menyatakan puas terhadap pelaksanaan fungsi informasi, hiburan, dan fungsi kontrol Jatiluhur TV sebagai televisi lokal, masih terdapat sebagian kecil masyarakat yang menyatakan tidak puas dengan pelaksanaan fungsi televisi terutama dalam bidang pendidikan.

Ketidakpuasan masyarakat bisa disebabkan pada penilaian bahwa siaran Jatiluhur TV masih kurang dalam memberikan kesempatan, waktu yang kurang memadai dalam menyampaikan siaran yang memberikan pendidikan yang berhubungan langsung dengan peningkatan taraf hidup masyarakat.

Media televisi dengan segala keterbatasan dan kelebihan yang dimilikinya dapat memberikan pemenuhan kebutuhan masyarakat karena teknologi informasinya, teknologi medianya, waktu dan materi siarannya. Dengan teknologi yang dimilikinya, televisi dapat melakukan editing tentang teknik pandangan (angle dan background) melalui sistem komputerisasi. Materi siaran budaya lokal dapat dikemas melalui tata panggung (stage) dan tata cahaya (lighting) bahkan melakukan animasi yang dapat menimbulkan estetika yang lebih baik dari tampilan aslinya.

Keberadaan atau eksistensi lembaga penyiaran televisi lokal dalam program siarannya sebagian besar mengarah kepada potensi yang ada di wilayahnya, seperti kebudayaan, potensi daerah, disamping melaksanakan fungsi-fungsi yang lainnya seperti fungsi pendidikan, hiburan, informasi dan sebagai kontrol sosial. Sesuai dengan tujuannya, materi siaran yang paling menonjol adalah Budaya Sunda (lokal). Dalam siaran-siaran yang ditampilkan sudah mampu menyajikan Budaya lokal seperti kesenian-kesenian lokal, bahasa-bahasa lokal dan keadaan lainnya yang ada dan terjadi di wilayahnya..

\section{KESIMPULAN}

Kepemilikan sarana komunikasi dan media informasi sebagai salah satu sumber informasi sangat berpengaruh terhadap responden dalam memberikan memahami, mengetahui, serta memberikan tanggapannya terhadap fungsi media televisi. 
Masyarakat menilai bahwa program siaran Jatiluhur TV telah mencerminkan media televisi lokal melalui berbagai program siaran. Secara umum, masyarakat di Kabupaten Purwakarta menilai bahwa stasiun televisi lokal Jatiluhur TV telah mampu menjadi stasiun televisi lokal yang mencerminkan budaya lokal di Kabupaten Purwakarta. Masyarakat menilai bahwa keberadaan Jatiluhur TV bermanfaat dan dapat ikut menunjang budaya lokal yang ada di wilayah Jatiluhur.

Masyarakat menyatakan puas terhadap fungsi informasi, fungsi hiburan, dan fungsi kontrol yang dijalankan oleh Jatiluhur TV. Namun demikian, masyakat merasa tidak puas dengan fungsi pendidikan Jatiluhur TV sebagai lembaga penyiaran televisi lokal. Sekalipun masyarakat menyatakan puas terhadap pelaksanaan fungsi informasi, hiburan, dan fungsi kontrol Jatiluhur TV sebagai televisi lokal, masih terdapat sebagian kecil masyarakat yang menyatakan tidak puas dengan pelaksanaan fungsi televisi terutama dalam bidang pendidikan.

Media televisi dengan segala keterbatasan dan kelebihan yang dimilikinya dapat memberikan pemenuhan kebutuhan masyarakat karena teknologi informasinya, teknologi medianya, waktu dan materi siarannya.

Keberadaan atau eksistensi lembaga penyiaran televisi lokal dalam program siarannya sebagian besar mengarah kepada potensi yang ada di wilayahnya, seperti kebudayaan, potensi daerah, di samping melaksanakan fungsi-fungsi yang lainnya seperti fungsi pendidikan, hiburan, informasi dan sebagai kontrol sosial.

Berdasarkan realitas bahwa pesawat televisi merupakan media informasi yang paling dominan dimiliki masyarakat dan dijadikan sumber informasi utama, maka perlu adanya peran yang lebih dan idealisme tinggi dari Jatiluhuir TV sebagai stasiun televisi lokal, dan semua stasiun televisi lokal lainnya yang diarahkan kepada pemenuhan kebutuhan informasi masyarakat. Seluruh stasiun televisi hendaknya dapat melayani kebutuhan masyarakat yang berbasis komunitas (lokal). Kendati pun berfungsi sebagai sarana pemenuhan bagi semua orang, hendaknya ada segmentasi dan spesifikasi, karena secara sosiologis, ekonomi dan pertimbangan lainnya, diantaranya karena pemirsa Jatiluhur TV adalah masyarakat yang ada di wilayah Kabupaten Purwakarta yang tentu saja mempunyai kebutuhan dan karakteristik lokal yang khusus.

Selain faktor teknologi informasi, teknologi media dan semua kelebihan yang dimilikinya, Jatiluhur TV dan stasiun televisi lokal lainnya hendaknya dapat membangun dan menciptakan kedekatan psikologis dengan pemirsanya. Hal ini telah dibuktikan dengan data yang menyatakan bahwa stasiun TVRI nasional tetap dimintai di tengah persaingan teknologi media televisi. Hal ini terutama harus menjadi prioritas pengembangan bagi stasiun televisi lokal yang diselenggarakan oleh masyarakat setempat.

Pengelola Jatiluhur TV dan semua stasiun televisi lokal bersama-sama dengan pemerintah melalui instansi yang membidangi masalah media massa, informasi dan komunikasi, serta semua pihak yang terkait hendaknya meningkatkan sosialisasi tentang fungsi-fungsi televisi lokal khususnya, serta media massa pada umumnya. Pemahaman masyarakat tentang fungsi televisi lokal dapat dijadikan ukuran dalam menentukan pencapaian sasaran seperti yang terkandung dalam fungsi media televisi. Pemahaman, penilaian dan kepuasan masyarakat terhadap siaran Jatiluhur TV hendaknya menjadi kepuasan acuan bagi media televisi dalam menjalankan aktivitasnya.

\section{DAFTAR PUSTAKA}

Ardianto, Elvinaro, Erdiyana, Komala. 2004. Komunikasi Massa Suatu Pengantar. Bandung: Simbiosa Rekatama Media. Gerungan. 1996. Psikologi Sosial. Bandung : Eresco.

Severin, W.J. and J.W. Tankard, Jr. (2003). Teori Komunikasi: Sejarah, Metode, dan Terapan di Dalam Media Massa. Cetakan Ke-3. Jakarta: Prenada Media. 
Suryabrata.1983. Metode Penelitian. Jakarta : Raja Grafido.

Sumadiria, AS Haris.2005. Jurnalistik Indonesia. Bandung: Simbiosa Rekatama Media

\section{Sumber lainnya :}

Depdiknas. 2003. Kamus Besar Bahasa
Indonesia. Jakarta : Balai Pustaka.

Undang-Undang No.32 Tahun 2002 Tentang Penyiaran

\section{Internet :}

www.infoskripsi.com

www.scribd.com 